\title{
SISTEM INFORMASI PENDATAAN PELANGGAN DAN PENGELOLAAN TRANSAKSI PADA D\&D LAUNDRY BERBASIS JAVA
}

\author{
Sonia Irawan', Gilang Ryan Fernandes², Iwan Budiarso ${ }^{31}$ \\ ${ }^{12}{ }^{3}$ Universitas Indraprasta PGRI \\ Jalan Raya Tengah No 80, Kelurahan Gedong, Pasar Rebo, Jakarta Timur

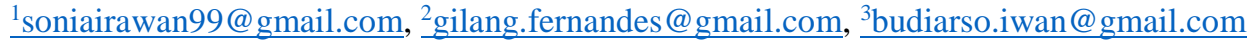

\begin{abstract}
ABSTRAK
Laundry umum disebut jasa cuci merupakan hal yang lumrah dikalangan masyarakat pada zaman ini, karena dengan adanya jasa laundry sangat membantu masyarakat yang memiliki kesibukan cukup padat, sehingga tidak perlu lagi memikirkan cucian kotor. Banyaknya masyarakat yang menggunakan jasa laundry membuat pihak laundry kesulitan dalam melakukan pendataan, ditambah lagi jumlah pakaian cukup banyak sehingga kemungkinan terjadinya kesalahan dalam melakukan pendataan dan perhitungan yang kurang akurat. Peneltian yang dilakukan bertujuan untuk meningkatkan kinerja serta memudahkan dalam mengelola data pelanggan dan transaksi serta dalam pembuatan laporan sehingga meminimalkan terjadinya kesalahan dalam pendataan dan perhitungan transaksi. Metode penelitian yang digunakan yaitu metode kualitatif mulai dari tahap wawancara sampai observasi langsung ke lapangan. Metode pengembangan yang digunakan yaitu model waterfall karena model ini sangat cocok dan mudah untuk melakukan pengembangan. Hasil dari penelitian ini sangat bermanfaat untuk meningkat kualitas kerja dan tersistematis sehingga mengurangi terjadinya kesalahan dalam pengolahan data, sehingga data yang dihasilkan akan lebih akurat.
\end{abstract}

Kata Kunci: Sistem Informasi, Pendataan Pelanggan dan Pengelolaan Transaksi, Java

\section{ABSTRACT}

Public laundry is called a washing service, which is commonplace among people today, because the existence of a laundry service really helps people who have quite a busy schedule, so they don't need to think about dirty laundry anymore. The number of people who use laundry services makes it difficult for the laundry party to collect data, plus the number of clothes is quite large so that there may be errors in data collection and inaccurate calculations. This research aims to improve performance and make it easier to manage customer data and transactions as well as in making reports so as to minimize errors in data collection and transaction calculations. The research method used is a qualitative method starting from the interview stage to direct observation to the field. The development method used is the waterfall model because this model is very suitable and easy to develop. The results of this study are very useful for improving the quality of work and systematically so as to reduce the occurrence of errors in data processing, so that the resulting data will be more accurate.

Key Word: Information Systems, Customer Data Collection and Transaction Management, Java

\section{PENDAHULUAN}

Kemajuan teknologi terus berkembang dengan cepat seiring berjalannya waktu. Kecanggihan teknologi dapat membantu segala aspek kehidupan dalam menyampaikan informasi serta menyebarkan informasi. Perkembangan teknologi tentunya tak luput dari media elektronik salah satunya komputer.

Dengan kemajuan teknologi ini, banyak pemilik usaha kecil yang sudah menggunakan sistem terkomputerisasi, tetapi masih banyak pemilik laundry yang belum menggunakan teknologi komputer untuk mempermudah pekerjaannya. Kebanyakan jasa usaha laundry adalah usaha kecil atau usaha keluarga, sehingga dalam pengelolaannya dilakukan secara sederhana seperti D\&D Laundry yang masih menggunakan cara manual dalam pendataannya. Laundry ialah sebuah departemen yang awalnya hanya untuk kegiatan pencucian pada operasional hotel dan tamu hotel, namun sekarang sudah berkembang sesuai dengan kebutuhan masyarakat yang membutuhkan jasa cuci (Yaqin, 2016:36).

Dalam pengelolaan data dan pencatatan jasa laundry, D\&D Laundry melakukan pencatatan data ditulis tangan menggunakan sebuah buku. Sehingga D\&D Laundry kesulitan dalam melakukan pendataan serta pembuatan laporan laundry. Pembuatan nota dan laporan transaksi juga masih dibuat secara manual serta 
memungkinkan terjadinya kesalahan dalam melakukan penghitungan. Sering terjadinya kehilangan data karenakan kesalahan penempatan berkas yang mengakibatkan data tidak bisa dipercaya lagi tingkat ke akuratannya. Banyak penggunaan buku dan alat tulis lainnya membuat terjadinya penumpukan data dan biaya pembelian alat tulis yang cukup boros. Belum adanya sistem juga memungkinkan terjadinya kecurangan pada saat proses transaksi seperti manipulasi data dan sering terjadinya human error.

Sistem merupakan program kegiatan perusahaan berdasarkan model yang terintegrasi (Mulyadi, 2016:5). Selain itu, sistem merupakan suatu unsur yang terikat dan berjalan seusai dengan kepentingan masing-masing. Setiap sistem mempunyai suatu fungsi yang berbeda tergantung pada situasi atau kasus yang akan dipelajari (Azhar, 2013:22).

Dengan dibuatkannya sistem informasi yang terkomputerisasi diharapkan mampu mengatasi permasalahan yang ada. Serta memberikan solusi terbaik demi meningkatkan kinerja pegawai dan juga bermanfaat untuk kenyamanan pelanggan D\&D Laundry.

\section{METODE PENELITIAN}

Metode penelitian berfungsi untuk mempermudah dalam pengumpulan data untuk membuat sistem. Untuk membangun sistem informasi yang baik dan sesuai kebutuhan maka, penggunaan metode kualitatif menjadi pilihan penulis dalam melakukan penelitian. Metode kualitatif adalah suatu penelitian berdasarkan kecenderungan analisis serta menekankan pada proses dan makna (sudut pandang objek).

Adapun metode pengumpulan data yang digunakan untuk membangun sistem informasi D\&D Laundry, adalah sebagai berikut:

\section{Wawancara}

Dalam wawancara, penulis sudah menyiapkan berbagai pertanyaan, namun muncul berbagai pertanyaan lain selama proses penelitian dan sangat membantu penulis untuk mendapatkan informasi data yang lengkap.

2. Metode Observasi

Observasi dilakukan secara langsung di lapangan dengan mengamati sistem yang berjalan pada D\&D Laundry serta melakukan pencatatan untuk memenuhi kebutuhan penelitian.

3. Sumber Data Melalui website yang ada di internet

Pada tahap ini pencarian teori dengan peninjauan beberapa website untuk mengumpulkan artikel dan kutipan yang berkaitan dengan penelitian ini.

Untuk melakukan perincian terhadap masalah yang dihadapi pihak laundry maka, dilaukan analisis permasalahan. Analisis permasalahan adalah kegiatan untuk mengidentifikasi elemen-elemen situasi dalam masalah dan memahami elemen mana yang kritis, serta mampu dalam memecahkan permasalahan untuk mendapatkan solusi. Untuk memecahkan permasalahan, maka digunakan diagram fishbone untuk merinci permasalahan. Fungsi utama diagram fishbone adalah untuk identifikasi dan mengelola kemungkinan adanya penyebab dari efek tertentu, dan kemudian membagi akar penyebabnya menjadi beberapa bagian (Rahmah, 2021). Berikut gambar diagram fishbone:

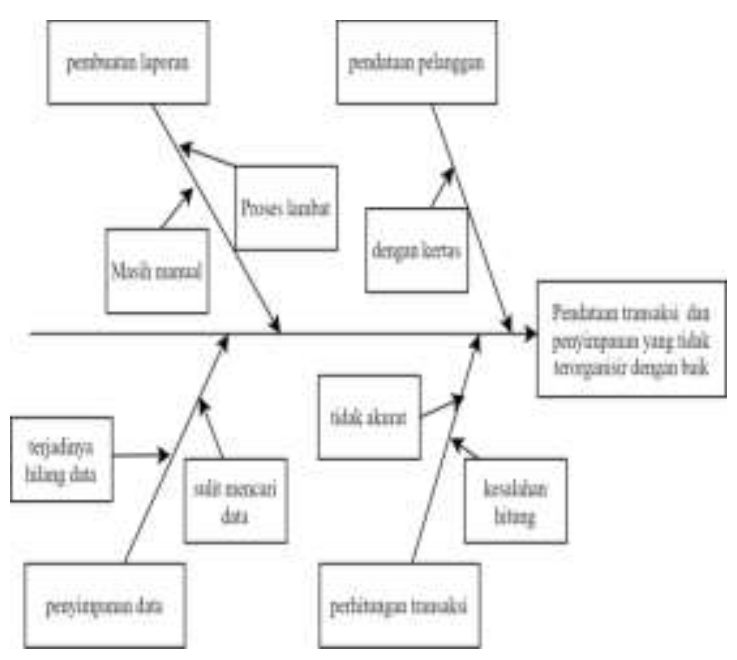

Gambar 1. Gambar Fishbone

Penulis memilih metode pengembangan Model Waterfall. Model Waterfall merupakan jenis model pengembangan dalam siklus hidup yang klasik berdasarkan pada urutan dan tahap sistem secara terstruktur dan sistematis (Pressman, 2015 : 46) Untuk model pengembangan ini mirip dengan air terjun, dimana setiap tahapan dijalankan secara berurutan dari atas ke bawah. Berikut alur pengembangan sistem dengan model Waterfall: 


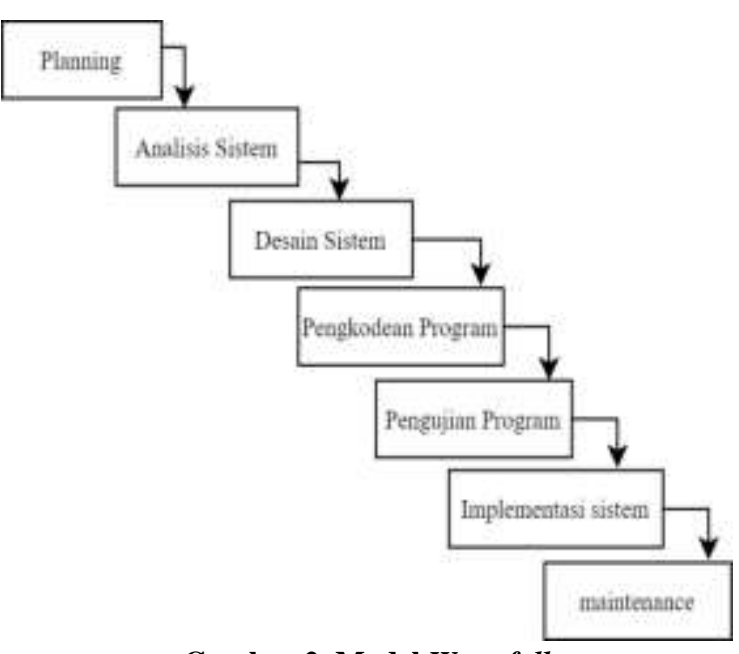

Gambar 2. Model Waterfall

\section{HASIL PEMBAHASAN}

Berdasarkan analisis masalahan yang sudah dirinci, penulis memberikan solusi untuk alternatif penyelesaian masalah yang ada pada D\&D Laundry yaitu dengan membuat sistem pendataan dan pengelolaan transaksi. Alur sistem tersebut dirinci dengan menggunakan diagram use case, diagram activity, dan diagram sequence. Untuk database menggunakan Entity Relationship Diagram, Transformasi ERD ke LRS dan Logical Record Structured.

Diagram use case merupakan gambaran fungsi sistem berdasarkan padangan pengguna. Use case berjalan dengan mengambarkan hubungan anatara user (pengguna) dengan sistem melalui sebuah gambar mengenai proses sistem dapat digunakan (Munawar, 2018 : 89) Berikut gambar diagram use case:

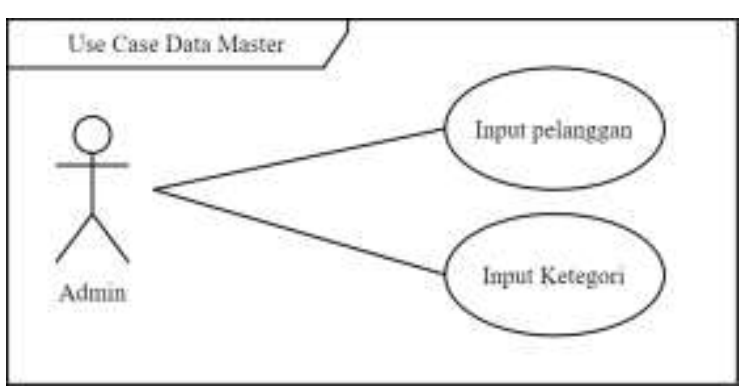

Gambar 3. Use Case Diagram Data Master

Berasarkan gambar diagram use case data master, admin memiliki akses terhadap dua data master yaitu pelanggan dan kategori.

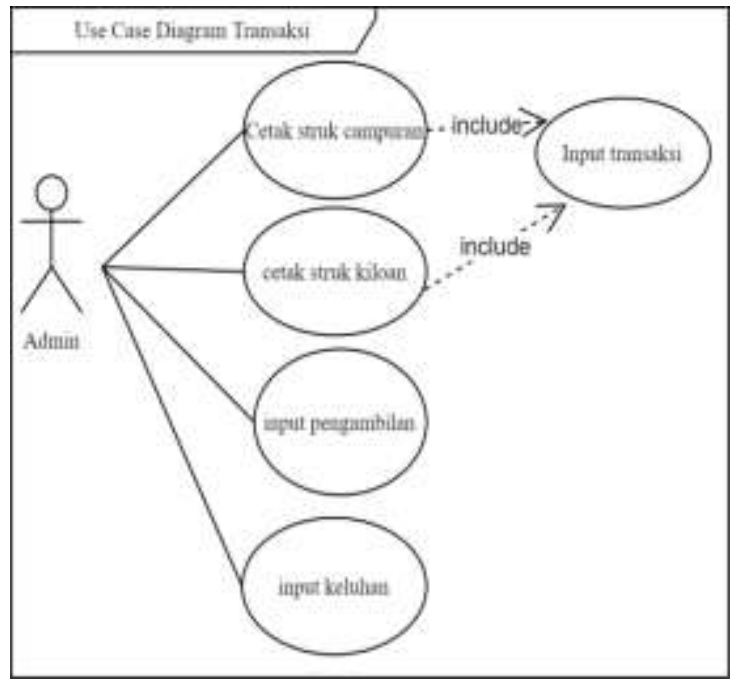

Gambar 4. Use Case Diagram Data Transaksi

Berdasarkan use case data transaksi, admin memiliki akses terhadap tiga data transaksi yaitu data transaksi, data pengambilan, dan data keluhan. Serta admin dapat melakukan cetak struk campuran dan kiloan.

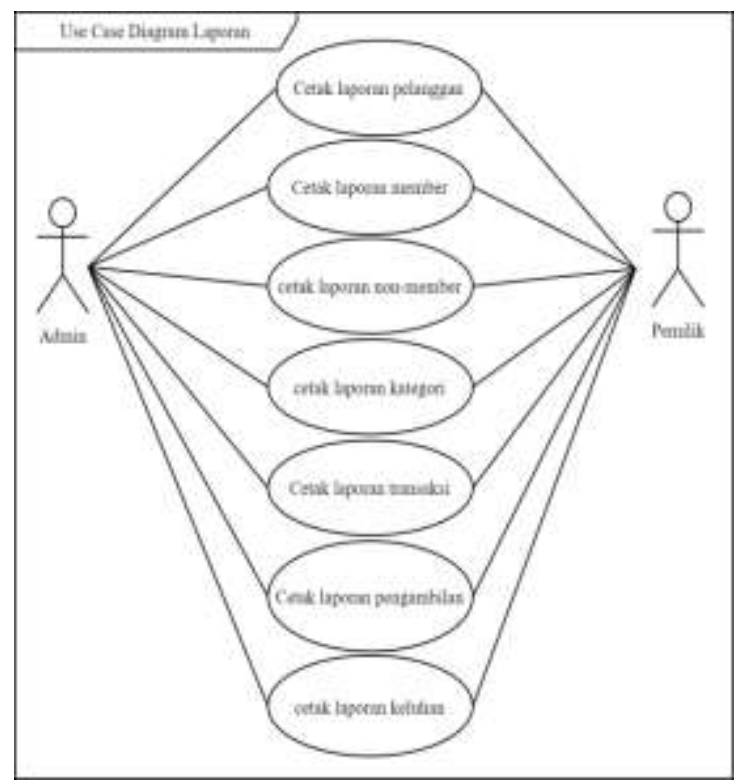

Gambar 5. Use Case Diagram Data Laporan

Gambar use case data laporan. Terdapat dua aktor pada diagram use case laporan, admin memiliki akses untuk melakukan cetak laporan dan pemilik juga berhak untuk mendapatkan laporan.

Diagram aktivitas didasarkan pada proses dasar dan alternatif dalam skenario diagram use case. Diagram aktivitas adalah gambaran aktivitas antara pengguna dan sistem dalam use case diagram (Anuttama, 2012 : 20). Berikut gambar activity diagram: 


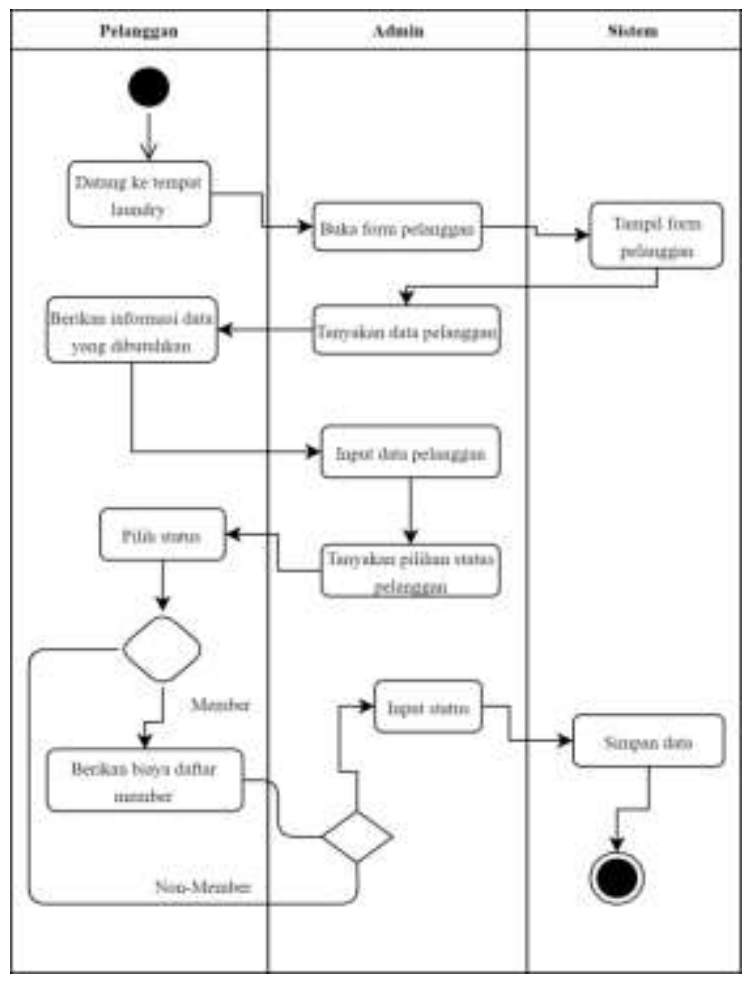

Gambar 6. Activity Diagram Pelanggan

Pada activity diagram pelanggan berisikan alur pendataan pelanggan, pelanggan memberikan datanya, kemudian admin menginput data dan sistem berfungsi untuk menyimpan data.

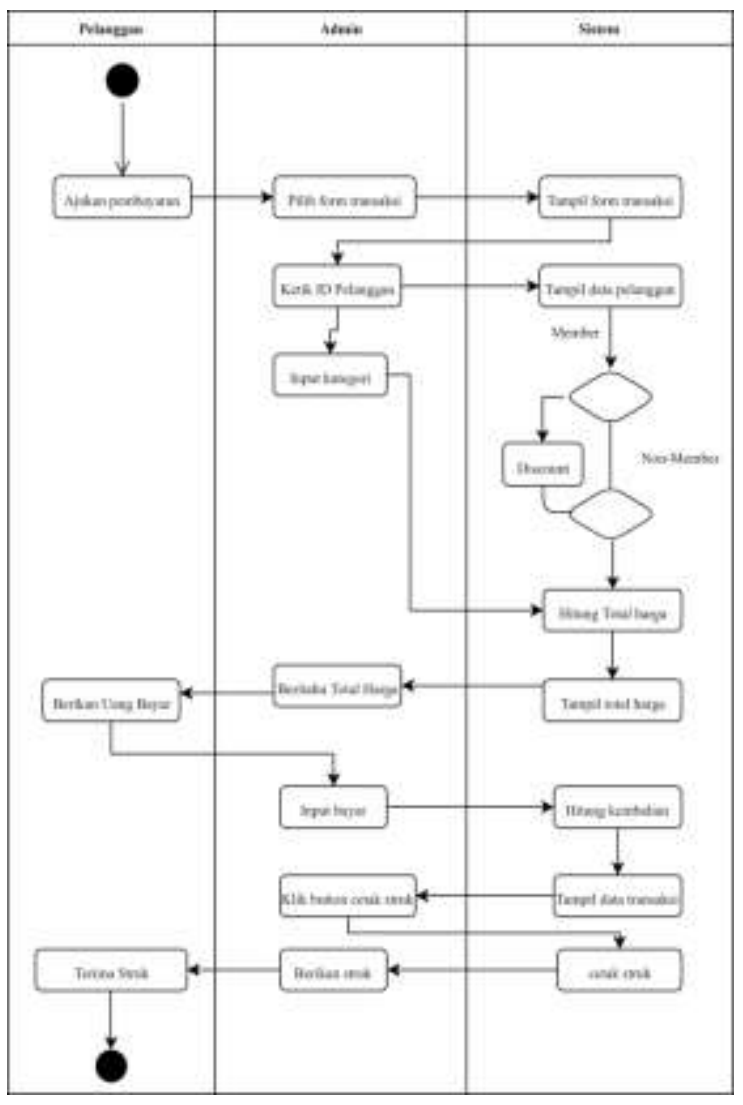

Gambar 7. Activity Diagram Transaksi
Pada Activity diagram transaksi berisikan alur pendataan transaksi, pelanggan mengajukan transaksi, kemudian admin menginput data dan sistem akan melakukan perhitungan biaya kemudian melakukan cetak struk dan menyimpan data transaksi.

Rancangan basis data untuk membuat aplikasi laundry yaitu, ERD (Entity Relationship Diagram), selanjutnya transformasi ERD ke LRS (Logical Record Structured), serta adapun gambaran dari LRS.

Dibawah ini merupakan Entity Relationship Diagram atau diagram relasi, adalah model data yang diekspresikan dalam bentuk simbol grafis dalam pemodelan data konseptual untuk menggambarkan hubungan antar penyimpanan (Zidniryi, 2020). Pada gambar ERD terdapat empat entitas yang saling berhubungan, selain itu pada relasi entitas transaksi dengan kategori menghasilkan entitas baru yaitu detail. Berikut gambar ERD:

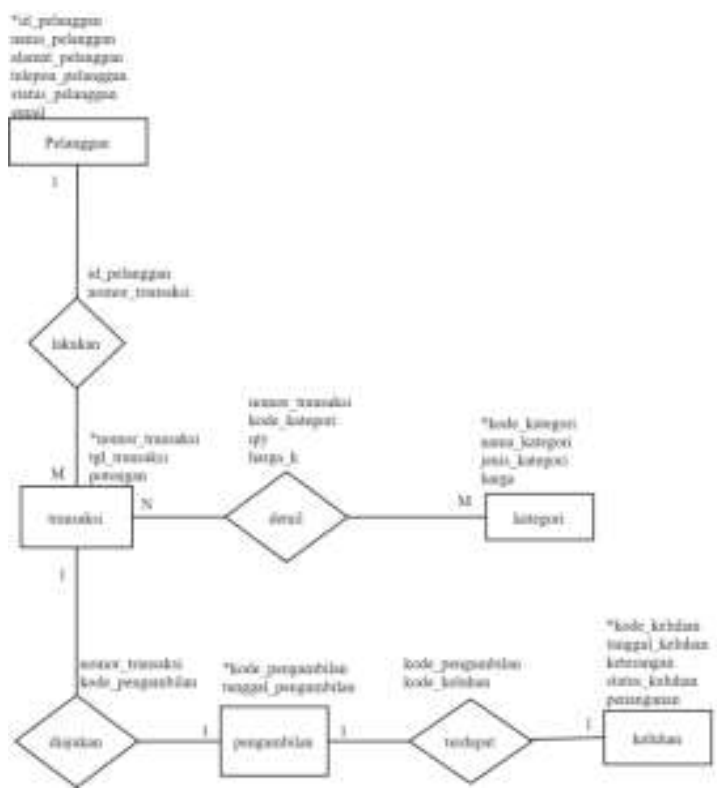

Gambar 8. ERD (Entity Relationship Diagram)

Dibawah ini dalah gambar Transformasi ERD, adalah proses mengubah data dari sebuah model menjadi tabel. Transformasi ERD adalah tabel database nyata. Pada transaformasi ERD dapat tergambarkan dengan jelas entitas yang memiliki keterkaitan sehingga diberikan penanda titik-titik untuk menujukkan secara penuh. Berikut gambar Transformasi ERD: 


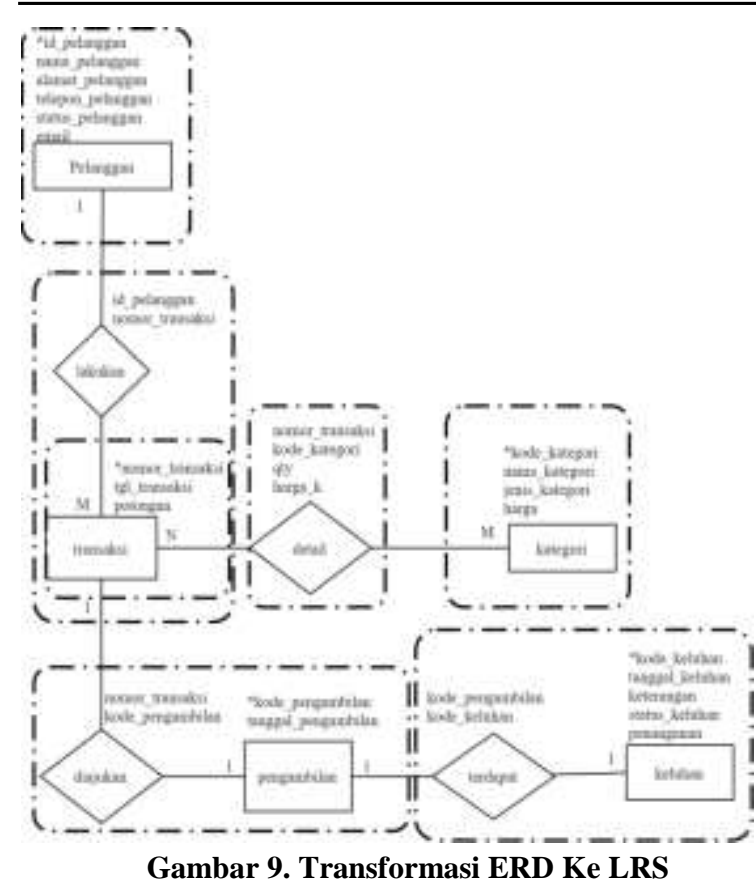

Logical Record Structure, terdiri dari jumlah tipe record. Beberapa jenis record yang dijelaskan dengan kotak persegi panjang dan memiliki nama yang unik (Wulandari, 2013: 17). Pada LRS yang digambarkan dibawah, menunjukkan bahwa ada suatu keterkaitan dari setiap tabelnya dan saling menarik primary key. Berikut gambar LRS:

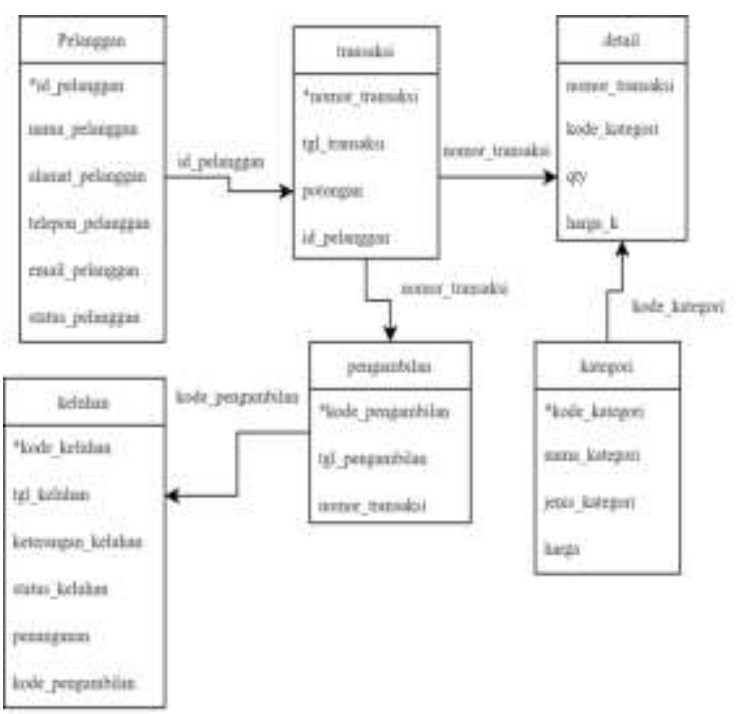

\section{Gambar 10. LRS (Logical Record Structure)}

Berdasarkan hasil dan pembahasan yang sudah dijelaskan diatas, penulis membuat sistem informasi pendataan pelanggan dan pengelolaan transaksi untuk mempermudah proses pengiolahan data pada D\&D Laundry. Berikut tampilan layar dari sistem yang dibuat:

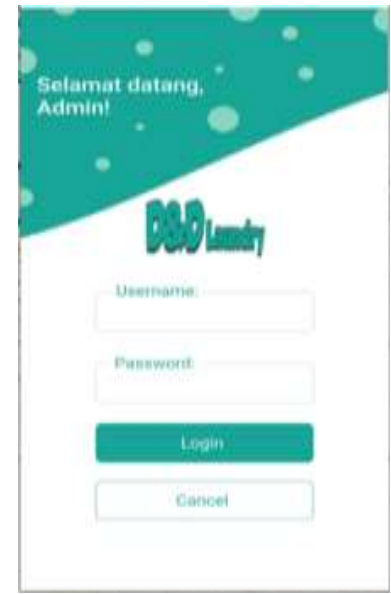

\section{Gambar 11. Tampilan Layar Form Login}

Tampilan layar login berfungsi untuk melakukan validasi sebelum masuk ke sistem dan untuk memastikan bahwa hanya admin yang dapat membuka aplikasi.

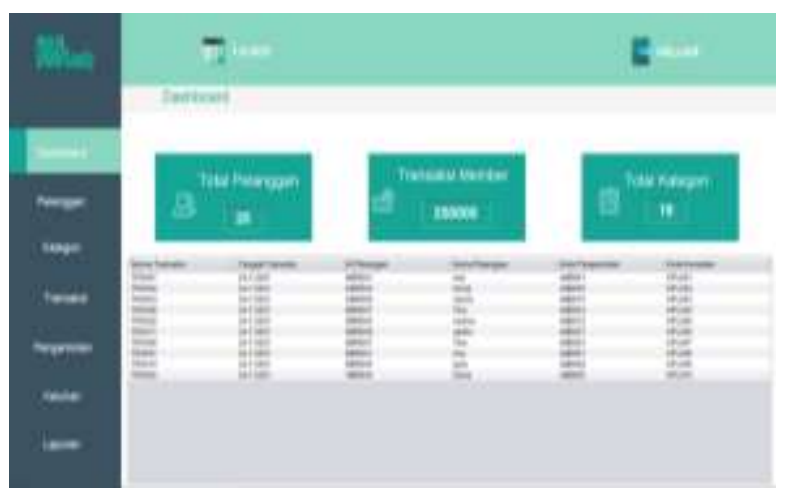

Gambar 12. Tampilan Layar dashboard

Tampilan layar dashboard berfungsi untuk melihat detail data berupa total pelanggan, transaksi member yaitu banyaknya biaya daftar member yang sudah masuk, total kategori.

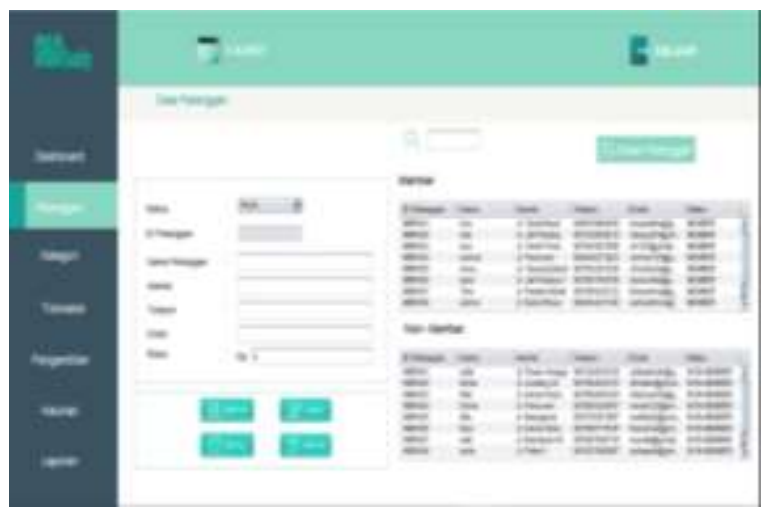

Gambar 13. Tampilan Layar Form Pelanggan

Tampilan form pelanggan terdapat dua tabel yaitu tabel member yang khusus untuk data pelanggan berstatus member, sedangkan tabel non-member hanya berisikan data pelanggan 
yang berstatus non-member. Kemudian pada form pelanggan juga terdapat inputan untuk mengisi data pelanggan.

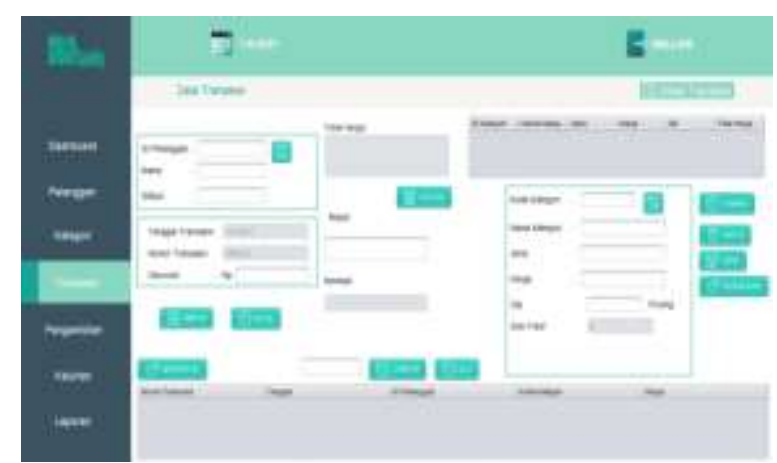

Gambar 14. Tampilan Layar Form Transaksi

Pada tampilan transaksi berfungsi untuk menginput data transaksi. Form transaksi berisikan inputan pelanggan, inputan transaksi dan inputan kategori, serta terdapat tabel untuk melihat detail transaksi. Admin juga dapat melihat detail transaksi yang ada.

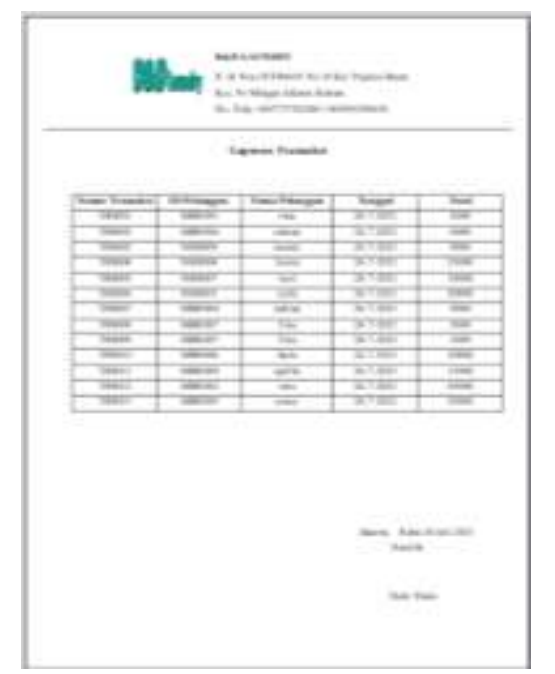

Gambar 15. Tampilan Layar Laporan Transaksi

Tampilan laporan transaksi bertujuan untuk mempermudah admin dan pemilik dalam melakukan pendataan transaksi yang berisikan nomor transaksi, id pelanggan, nama pelanggan, tanggal transaksi dan total transaksi.

Diagram sequence menggambarkan alur sistem, diagram sequence juga memberikan gambaran waktu pesan akan dialirkan dan dikirimkan kepada kelas yang dituju (Wijayanto, 2012:35). Berikut gambar Sequence Diagram:

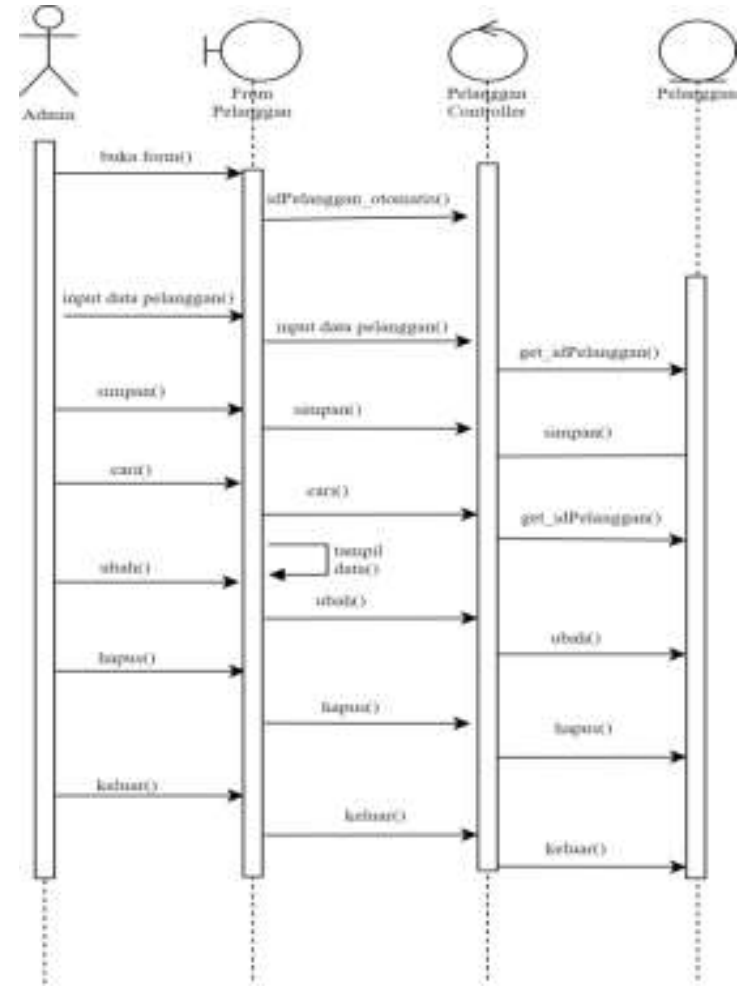

Gambar 16. Sequence Diagram Form Pelanggan

Sequence diagram pelanggan betujuan untuk menjelaskan alur sistem yang terdapat pada aplikasi untuk proses pendataan pelanggan. Sequence diagram form pelanggan dapat melakukan simpan, hapus dan ubah data serta dapat melakukan pencarian data.

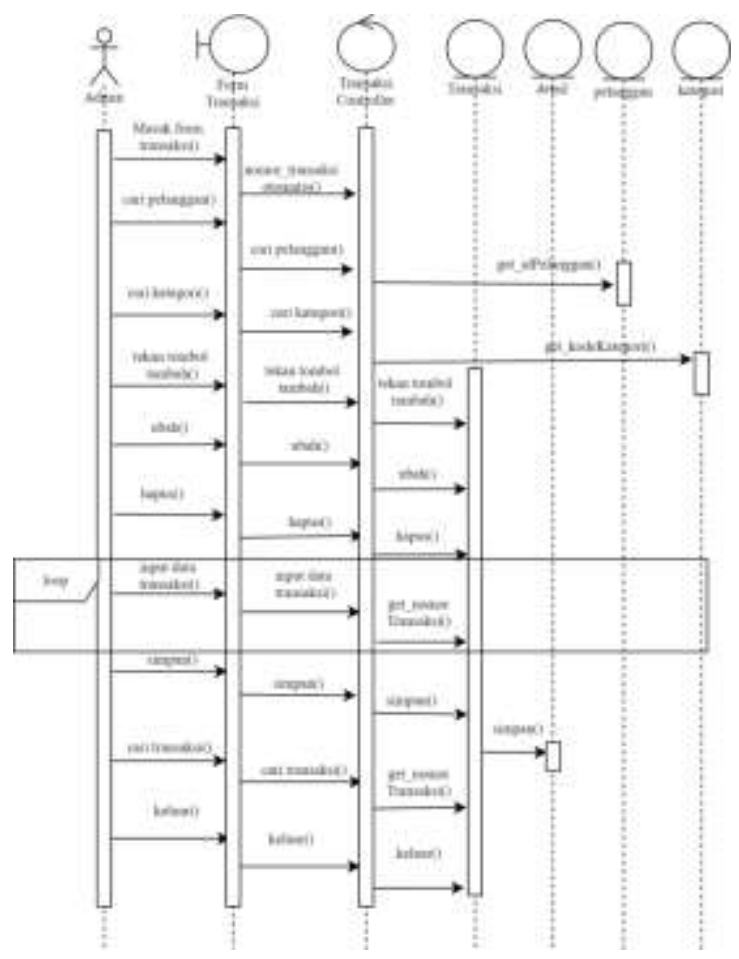

Gambar 17. Sequence Diagram Form Transaksi 
Pada sequence diagram transaksi terdapat alur sistem dimana admin harus masuk terlebih dahulu ke halaman form transaksi, kemudian melakukan input data, simpan data, ubah data dan admin dapat melakukan cetak struk.

\section{SIMPULAN DAN SARAN}

Dengan terselesaikannya perancangan sistem untuk pendataan laundry, penulis dapat menarik beberapa kesimpulan yaitu, sistem informasi ini dapat dijadikan alat bantu untuk mempercepat kinerja dalam melakukan pendataan dan transaksi. Selain itu, penyimpanan data akan disimpan ke dalam database sehinga data tidak akan tertata dengan baik dan mengurangi terjadinya kehilangan data. Sistem informasi ini juga dapat membuat laporan secara otomatis, sehingga mempercepat proses pembuatan laporan dan mengurangi terjadinya human error saat pembuatan laporan.

Adapun saran untuk mengembangkan sistem yaitu, sistem Informasi yang dibuat masih memiliki kekurangan sehingga perlu pengembangan yang sejalan dengan seiring kemajuan zaman. Selain itu, penambahan fitur pemesanan jasa laundry secara online dan adanya fitur kurir juga dapat menambahkan kesan menarik untuk pelanggan, serta bermanfaat untuk dapat dengan mudah memperluas jangkauan pelanggan. Untuk mengurangi kehilangan bukti faktur, sebaiknya sistem dikembangkan dengan menambahkan fitur SMS Gateway.

\section{DAFTAR PUSTAKA}

Anuttama, D. V. (2012). Analisis Perancangan Sistem Informasi Rawat Jalan Di Rumah Sakit Hewan Universitas Airlangga Surabaya Dengan Metode Berorientasi Objek. Universitas Airlangga. Universitas Airlangga.

Azhar, S. (2013). Sistem Informasi Akuntansi. Bandung: Lingga Jaya, 5(1).

Mulyadi. (2016). Sistem Informasi Akuntansi.

Munawar. (2018). Analisis Perancangan Sistem Berorientasi Objek dengan UML.

Pressman, R. (2015). Rekayasa Perangkat Lunak: Pendekatan Praktisi(Buku Dua).

Rahmah, A. (2021). Fishbone Diagram. Rumus.Co.Id. diakses dari: https://rumus.co.id/fishbone-diagram/

Wijayanto, T. (2012). Analisis dan Perancangan Sistem Informasi
Pemesanan dan Penjualan Barang dengan Metode Berorientasi Objek di UD Aneka Jaya Surabaya. Universitas Airlangga.

Wulandari, L. T. (2013). Desain dan Perancangan Sistem Informasi Akademik Pada STMIK Ubudiyah Indonesia Banda Aceh. Diambil Dari: Http://Lppm. Stikesubudiyah. Ac. Id/Jurnal/Lestari_Wulandari. $\quad T-T w l-$ Lestari_wulandari_mi. Pdf.

Yaqin, M. S. A. (2016). Analisis perancangan aplikasi layanan laundry berbasis Visual Basic 2010 dan SQL Server 2000 pada Gajayana Laundry. Semansteknomedia Online, 4(1), 2-9.

Zidniryi. (2020). Pengertian ERD, Fungsi, Simbol ERD Dan Contoh ERD. KonsepKoding(). https://www.konsepkoding.com/2020/05/ pengertian-erd-fungsi-erd-contoherd.html 